\title{
Milk-substitutes comparable to rat's milk; their preparation, composition and impact on development and metabolism in the artificially reared rat
}

\author{
By NANCY AUESTAD*, ROSE A. KORSAK, JAMES D. BERGSTROM† \\ AND JOHN EDMOND \\ Department of Biological Chemistry and the Mental Retardation Research Center, UCLA \\ School of Medicine, Los Angeles, CA 90024-1737, USA
}

(Received 1 July 1988 - Accepted 20 December 1988)

1. Procedures are described to prepare nutritionally adequate rat milk-substitutes by modifying commercially available processed cow's milk, rich in carbohydrate and low in protein and fat compared with rat's milk.

2. Premilk formulas, prepared as intermediates in the preparation of rat milk-substitutes, are rich in protein but low in their concentration of fat, carbohydrate, and minerals when compared with rat's milk.

3. Premilks were supplemented with lactose, vitamins, minerals, fat as oil mixtures, certain amino acids and other constituents to yield rat milk-substitutes which resemble the known composition of rat's milk in their properties and composition.

4. Detailed analyses of the milk-substitutes show them to be comparable to rat's milk in energy content, $\mathrm{pH}$, osmolarity, the concentration of the macronutrients, fat, protein and carbohydrate, and the major minerals.

5. Rat pups were artificially reared from postnatal day 4 or 5 until days $16-18$ by fitting them with gastric cannulas through which the milk-substitutes could be infused automatically.

6. The nutritional impact of the milk-substitutes was assessed by a comparison of growth and metabolic characteristics for artificially reared rats with age-matched sucking rats reared by their mother.

7. Indices which were taken to be appropriate included $(a)$ body-weight gain; $(b)$ the concentration in blood of protein, amino acids, ketone bodies, carnitine, glucose, galactose, lactate, insulin, and the electrolytes calcium, sodium, potassium and chloride; $(c)$ the turnover of glucose and 3-hydroxybutyrate; $(d)$ the concentration in brain of protein, cholesterol, cerebroside sulphate and the activities of the enzymes pyruvate dehydrogenase $(E C$ 1.2.4.1), 3-oxo-acid-CoA transferase (EC 2.8.3.5) and acetoacetyl-CoA ligase (EC 6.2.1.16).

8. The studies suggest that milk-substitutes approximating to rat's milk in composition promote acceptable metabolism in the artificially reared rat pup.

A semi-automated system for the artificial rearing of rat pups from about $4 \mathrm{~d}$ after birth to weaning at $21 \mathrm{~d}$ of age was first described by Messer et al. (1969) and has been used in studies dealing with behavioural (Hall, 1975), pharmacological (Diaz \& Schain, 1977, 1978) and metabolic and nutritional (Diaz et al. 1982; Sonnenberg et al. 1982; West et al. 1982; Smart et al. 1984) aspects of development during the suckling period for the infant rat. The rat milk-substitute that has been used in these studies contains $300 \%$ of the carbohydrate and $60 \%$ of the protein concentration of rat's milk (Messer et al. 1969). It has been shown that developmental and metabolic events are suboptimal in rat pups reared exclusively on this milk-substitute (Sonnenberg et al. 1982; Smart et al. 1984). The synchrony of nutrients available in rat's milk with events that occur in intermediary metabolism promotes optimal growth and development in the neonatal rat. Thus, for studies with artificially reared rats it is necessary to have available a rat milk-substitute which is similar to rat's milk in its basic constituents and which can promote normal events in intermediary metabolism.

Two procedures that can be used to modify commercially available cow's-milk products to formulate rat milk-substitutes similar to rat's milk in composition are described. The

Present addresses: * Department of Pediatrics, The Research Centre, University of British Columbia, 950 West 28th Avenue, Vancouver, B.C. V5Z 4H4, Canada. † Merck, Sharp and Dohme Research Laboratorics, 80 W-250, Box 2000, Rahway, NJ 07065-0900, USA.

$\ddagger$ For reprints. 
major difference between the two procedures is that one can be routinely carried out with basic laboratory equipment and commercially available reagents, while the other requires specialized equipment.

Details of the composition of premilks, prepared as intermediate protein-rich bases, and the rat milk-substitutes are presented in addition to an evaluation of the capacity of the milk-substitutes to promote normal metabolic and developmental events in artificially reared rat pups. Many of the specific indices that were evaluated were selected on the basis of our previous observations that rats reared on the diet described by Messer et al. (1969) exhibited atypical patterns in blood for metabolites of fat, carbohydrate and protein utilization (Sonnenberg et al. 1982). In addition, we focused on an evaluation of the development of the brain and gastrointestinal tract.

\section{MATERIALS AND METHODS}

Preparation of milk-substitutes

\section{Rat milk-substitute-2A (RMS-2A)*}

The rat milk-substitute (RMS-2A) was prepared in two steps. The preparation of a premilk base precedes the formulation of RMS-2A. The key features of the protocol for the preparation of the premilk from cow's-milk fractions were a dialysis step, which reduced the concentration of lactose, followed by a concentration step that substantially increased the protein concentration. This resulted in a premilk base which contained a normal concentration of protein, but was deficient in its fat, carbohydrate and ash content when compared with rat's milk. The appropriate quantities of fat, carbohydrate, minerals, vitamins and amino acids were then added to prepare the final RMS-2A.

Preparation of premilk base A. Skim-milk powder (366 g; Teklad, Madison, WI) was slowly added to $750 \mathrm{ml}$ evaporated milk (Carnation Corp., Los Angeles, CA) with continuous stirring by hand. The mixture was stirred until smooth and poured into a $3 \mathrm{~m}$ length of standard cellulose dialysis tubing (molecular weight limit 12000-14000, dry cylinder diameter $27 \mathrm{~mm}$; Fisher Scientific Co., Pittsburgh, PA). The tubing was soaked in distilled water for $1 \mathrm{~h}$ before use. The sample was dialyzed against 16 litres distilled water at $4^{\circ}$ for $1.5 \mathrm{~d}$ with two water changes (total volume of water, 48 litres). A minimum of 6 $\mathrm{h}$ elapsed before each change of water. The total volume of the dialyzed sample was approximately $2400 \mathrm{ml}$. The sample was divided among ten $290 \mathrm{ml}$ capacity wide-mouth PMP Nalgene bottles (American Scientific Products, McGaw Park, IL) and balanced in pairs by weight before freezing at $-20^{\circ}$. The sample was then thawed slowly overnight at $4^{\circ}$, taking care not to disturb the bottles. This freeze-thaw procedure resulted in precipitation and concentration of the solutes in the milk. The bottles were centrifuged for $20 \mathrm{~min}$ at $800 \mathrm{~g}$ using a Beckman J6B centrifuge (Beckman, Palo Alto, CA) containing a JS 4.2 swinging bucket rotor with an average radius of $184 \mathrm{~mm}$. Most of the supernatant fraction was then removed by aspiration and retained. The concentrates were then combined. Some of the retained supernatant fraction was used to rinse the bottles. The combined concentrate was homogenized for $45 \mathrm{~s}$ at medium speed using a polytron with a PT45 generator (Brinkmann Instruments, Inc., Westbury, NY). The concentrate was degassed overnight at $4^{\circ}$ under vacuum. The volumes of the degassed concentrate and the retained supernatant fraction were measured. The appropriate volume of the supernatant fraction was added to the degassed concentrate such that the final volume of the concentrated milk sample (premilk base) was $70 \%$ of the total volume of the dialyzed sample. 
Preparation of $R M S-2 A$. RMS-2A was prepared by mixing appropriate quantities of fat, carbohydrate, minerals, vitamins, amino acids and other components as listed in Table 1 into the premilk base. Maize oil, safflower oil, and the vitamin mix (no. 40060) were purchased from Teklad, Madison, WI. MCT oil was purchased from Mead Johnson, Evansville, IN and contained octanoic acid and decanoic acid at 68 and $24 \%$ by weight respectively. Carnitine was purchased from P.L. Biochemicals, Milwaukee, WI. All other components were purchased from Sigma Chemical Co., St Louis, MO.

The mixture of the premilk base and other components was then homogenized for $60 \mathrm{~s}$ at medium speed using a polytron with a PT45 generator. The milk (RMS-2A) was then frozen and stored in batches of $150-250 \mathrm{ml}$ at $-20^{\circ}$. The milk was thawed, homogenized for $15 \mathrm{~s}$ at high speed using a Waring Blendor, and degassed at $4^{\circ}$ under vacuum before being given to rat pups.

Analysis of RMS-2A. The premilk base and RMS-2A were analysed by Morning Star Labs, Los Angeles, CA and by Bioserv Inc., Frenchtown, NJ. The estimated error (\%) in the analyses of each component (1) by Morning Star Labs was: fat 2, protein 5, carbohydrate 20 , lactose 10 , ash 10 , minerals $12 ;(2)$ by Bioserv Inc. was: fat $3-5$, protein and ash 3-7, carbohydrate and lactose 5-10, sodium, potassium, phosphorus, calcium and iron 3-7, copper and zinc 5-10, chloride and magnesium 10-15. The estimated error $(\%)$ in the analyses of individual fatty acids by Bioserv Inc. was 2 .

\section{Rat milk-substitute-2B (RMS-2B)}

The rat milk-substitute, RMS-2B, was prepared by a modification of the method described previously for RMS-2A. In this procedure whey protein was first isolated from commercially available non-fat milk (Jerseymaid Milk Products Co., Los Angeles, CA) and saved until the final step of preparing the premilk base. The preparation of the premilk base, premilk-B, was simplified from the method of preparing premilk-A by including a simultaneous dialysis and concentration step automated by use of the Amicon DC10L Diaflo System (Amicon Corporation, Boston, MA). The system was operated according to the manufacturer's instructions. The result of these modifications was a premilk base with a slightly higher concentration of protein than that in premilk A and a lower casein: whey ratio. Minor modifications were also made in some of the other constituents added to premilk-B to formulate RMS-2B (Table 1). According to the following protocol approximately 4 litres RMS-2B were prepared per batch.

Isolation of whey protein. Whey protein was isolated from commercially available nonfat milk by a modification of the method of Woodward \& Messer (1976). Twenty litres of non-fat milk were processed per batch ( 4 litres) of RMS-2B. The non-fat milk was acidified by adding $25 \mathrm{ml} \mathrm{3.4} \mathrm{M}$-acetic acid to each litre of milk at room temperature. The acidified milk was centrifuged at $10000 \mathrm{~g}$ for $20 \mathrm{~min}$ using a Sorval RC2B centrifuge (Ivan Sorval, Inc., Newton, CT) at $25^{\circ}$. Each litre of supernatant fraction was neutralized with $40 \mathrm{ml} 2$ M-sodium hydroxide. The neutralized whey was dialyzed and concentrated in the Amicon DC10L Diaflo System containing a hollow-fibre cartridge (molecular weight limit: 10000), which was maintained at $4^{\circ}$ in the cold room. The whey was dialyzed against approximately 100 litres deionized distilled water until the conductivity of the dialysate was less than 45 $\mu \mathrm{S} / \mathrm{cm}$ (CPM83 Conductivity Meter; Radiometer, Copenhagen, Denmark). It was then concentrated to a volume of 2 litres and stored at $4^{\circ}$ while the premilk base was prepared (approximately 24-36 h).

Preparation of the premilk base $B$. Non-fat dry milk $(732 \mathrm{~g}$; Smart and Final Iris Company, Los Angeles, CA) was slowly added to 1.5 litres Carnation evaporated milk (Carnation Corporation, Los Angeles, CA) diluted with 2 litres deionized water and was stirred continuously at room temperature until all the milk powder was in solution. It was 


\section{Table 1. Preparation of rat milk-substitutes, $R M S-2 A$ and $R M S-2 B$}

(The amounts of each of the components that were included to prepare the rat milk-substitutes are as described on p. 496. Whey protein and medium-chain triglyceride (MCT) mix (Capital City Products, Janesville, WI) were not included in the preparation of RMS-2A since they were not available over the period of our studies with this milk-substitute)

\begin{tabular}{|c|c|c|}
\hline & RMS-2A & RMS-2B \\
\hline \multicolumn{3}{|l|}{ Premilk base (per batch) } \\
\hline Whey protein & Not included & $\begin{array}{l}\text { Isolated from } 20 \text { litres } \\
\text { non-fat milk* }\end{array}$ \\
\hline Skim-milk powder (g) & $366 \dagger$ & $732 \ddagger$ \\
\hline Evaporated milk (m]) & 750 & $1500^{+}$ \\
\hline \multicolumn{3}{|c|}{ Rat milk-substitute ( $\mathrm{g} / \mathrm{l}$ estimated final volume) } \\
\hline Premilk base $(\mathrm{ml})$ & 910 & 910 \\
\hline \multicolumn{3}{|l|}{ Fat $(\mathrm{g})$} \\
\hline Maize oil & 46 & 41 \\
\hline MCT mix $\S$ & - & $47 \cdot 4$ \\
\hline MCT oill & 40 & 5.6 \\
\hline Soya-bean oil & - & 26 \\
\hline Safflower oil & 2 & 一 \\
\hline \multicolumn{3}{|l|}{ Carbohydrate $(\mathrm{g})$} \\
\hline Lactose & 10 & $27 \cdot 5$ \\
\hline \multicolumn{3}{|l|}{ Minerals and vitamins (g) } \\
\hline Mineral mix (as a powder) & $11 \cdot 9$ & 11.9 \\
\hline \multicolumn{3}{|l|}{ Minerals in solution** } \\
\hline $\mathrm{CuSO}_{4} \cdot 5 \mathrm{H}_{2} \mathrm{O}$ & 0.03 & $0 \cdot 03$ \\
\hline $\mathrm{ZnSO}_{4} .7 \mathrm{H}_{2} \mathrm{O}$ & & 0.053 \\
\hline Vitamin mix ${ }^{\circ} \dagger$ & $4 \cdot 0$ & $4 \cdot 0$ \\
\hline Vitamin mix $+\ddagger$ & $1 \cdot 13$ & 0.55 \\
\hline \multicolumn{3}{|l|}{ Amino acids (g) } \\
\hline Arginine & 0.5 & 0.5 \\
\hline Glycine & $0 \cdot 3$ & $0 \cdot 3$ \\
\hline Taurine & $0 \cdot 15$ & $0 \cdot 15$ \\
\hline \multicolumn{3}{|l|}{ Other components $(\mathrm{g})$} \\
\hline Carnitine & 0.04 & 0.04 \\
\hline Picolinic acid & 0.02 & 0.02 \\
\hline Ethanolamine & & 0.034 \\
\hline Final volume (litres) & 1.85 & $4 \cdot 10$ \\
\hline
\end{tabular}

* Isolated from non-fat milk by the method of Woodward \& Messer (1976).

+ Purchased from Teklad, Madison, WI.

\$ Purchased from Smart and Final Iris, Inc., Los Angeles, CA.

$\S$ Custom prepared by Capital City Products, Janesville, WI.

I| Obtained from Mead Johnson, Evansville, IN.

I Prepared according to our formulation; all salts were purchased from Sigma Chemical Co., St Louis, MO (mg/g mix): $\mathrm{CaCO}_{3} 382, \mathrm{KH}_{2} \mathrm{PO}_{4} 375, \mathrm{KCl} 61, \mathrm{MgSO}_{4} 40, \mathrm{NaCl} 138, \mathrm{FeSO}_{4} \cdot 7 \mathrm{H}_{2} \mathrm{O} 2 \cdot 65, \mathrm{KI} 0 \cdot 153, \mathrm{NaF} 0 \cdot 130$, $\mathrm{AlSO}_{4} 0.083, \mathrm{MnSO}_{4} 0.023$.

** $\mathrm{Cu}$ and $\mathrm{Zn}$ salts (listed in $\mathrm{g}$ ) were added as solutions in water: the $\mathrm{Cu}$ sulphate solution was $30.9 \mathrm{~g}$, $\mathrm{CuSO}_{4} .5 \mathrm{H}_{2} \mathrm{O} / \mathrm{l}\left(0.97 \mathrm{ml} / \mathrm{I}\right.$ milk provided $\left.0.03 \mathrm{~g} \mathrm{CuSO}_{4} .5 \mathrm{H}_{2} \mathrm{O}\right)$; the $\mathrm{Zn}$ sulphate solution was $379.3 \mathrm{~g}$ $\mathrm{ZnSO}_{4} \cdot 7 \mathrm{H}_{2} \mathrm{O} / 1\left(0.14 \mathrm{ml} / 1\right.$ milk provided $\left.0.053 \mathrm{~g} \mathrm{ZnSO}_{4} \cdot 7 \mathrm{H}_{2} \mathrm{O}\right)$.

$\dagger \uparrow$ Purchased from Teklad (mg/g mix): p-aminobenzoic acid 11.01 , ascorbic acid, coated (97.5\%) 101.66, biotin 0.0441 , cyanocobalamin $(0.1 \%$ trituration in mannitol) 2.9736 , calcium pantothenic acid 6.6079 , choline dihydrogen citrate 349.69 , folic acid $0 \cdot 1982, \psi$-inositol 11.0132, menadione 4.9559 , nicotinic acid $9 \cdot 9119$, pyridoxine hydrochloride $2 \cdot 2026$, riboflavin $2 \cdot 2026$, thiamin hydrochloride $2 \cdot 2026$, dry retinyl palmitate $(275$ $\mathrm{mg} / \mathrm{g}) 3 \cdot 9648$, dry ergocalciferol $(12.5 \mathrm{mg} / \mathrm{g}) \quad 0.4405$, dry $\alpha$-tocopheryl acetate $(500 \mathrm{mg} / \mathrm{g}) 24 \cdot 2291$, maize starch 466.69 .

4+ Prepared according to our formulation; all vitamins were purchased from Sigma Chemical Co. (mg/g mix): $\psi$-inositol 824 , ascorbic acid 141 , nicotinic acid $18 \cdot 6$, riboflavin $9 \cdot 7$, pyridoxine $6 \cdot 7$. 
then placed in the reservoir of an Amicon DC10L Diaflo System containing a hollow-fibre cartridge (molecular weight limit: 10000). Deionized water was added to increase the volume to the 17 litres mark and the solution was dialyzed and concentrated against approximately 200 litres deionized water over a period of $36 \mathrm{~h}$.

Deionized water was prepared by a 5 cartridge Milli-Q Reagent Water System (Millipore, MA) consisting of a super cartridge, two ion-exchange cartridges, an organex $\mathrm{Q}$ cartridge, an UF pyrogen-free ultrafilter cartridge and a $0.2 \mu \mathrm{m}$ millistak filter. The conductivity of the deionized water was less than $1.0 \mu \mathrm{S} / \mathrm{cm}$.

The dialysis was achieved by circulating deionized water (Solid State Varistaltic Pump, model 475; Manostat Corp., NY) from a 50 litre capacity reservoir containing 45 litres water through the hollow-fibre cartridge at 2 litres $/ \mathrm{min}$ for at least $8 \mathrm{~h}$. This dialysis protocol was repeated four times. During dialysis, the milk in the Diaflo chamber was concentrated as the dialysate was transferred through the hollow-fibre cartridges to the circulating deionized water; as a result the volume of water in the reservoir increased. The conductivity of the water was about $1100,310,110$, and less than $40 \mu \mathrm{S} / \mathrm{cm}$ at the end of each dialysis period. When the conductivity of the dialysate was $50 \mu \mathrm{S} / \mathrm{cm}$ the isolated whey was added, The mixture was then concentrated to a volume of approximately $3 \cdot 6-4 \cdot 0$ litres as the final step in preparing the premilk base (premilk-B).

Preparation of RMS-2B. Components already listed for RMS-2A, with the exception of carnitine, were from the same sources. Carnitine was purchased from Sigma-tau, Inc., Holmodel, NJ. Soya-bean oil was purchased from Teklad, Madison, WI. The triacylglycerol mixture (Captex no. 8323) containing octanoic acid, decanoic acid and lauric acid at $14.3,44.7$ and $39.8 \%$ by weight was custom-synthesized by Capital City Products, Janesville, WI. Ethanolamine was purchased from Sigma Chemical Co. RMS-2B was prepared by mixing appropriate quantities of fat, carbohydrate, minerals, vitamins, amino acids and other components as listed in Table 1 into premilk-B. The mixture was first stirred by hand, then homogenized for two 30 s periods using a Polytron fitted with a PT35 generator. No more than 1 litre RMS-2B was prepared during each homogenization. Preparing more than 1 litre RMS-2B required homogenization at higher $\mathrm{rev} . / \mathrm{min}$ for a longer period and resulted in a substantial increase in the viscosity of the milk-substitute. The 1 litre batches of RMS-2B were combined, mixed, and poured into $110-\mathrm{ml}$ bottles for freezing at $-20^{\circ}$. Before RMS-2B was given to rat pups through the intragastric cannula, it was thawed and pumped through a hand homogenizer (Scientific Products Corp., Irvine, CA).

Analysis of RMS-2B. Premilk-B and RMS-2B were analysed by Bioserv Inc., Frenchtown, NJ. The variability in the analyses for each measurement was the same as listed for the analysis of RMS-2A.

\section{Animals}

For experiments with RMS-2A, Sprague-Dawley rats were purchased from the Simonsen Laboratory, Gilroy, CA and bred in our animal colony. Littermates were not separated. In the mother-reared control group (MR-A), litters of nine to eleven rat pups were reared with their mothers. In the artificially reared group (RMS-2A), an intragastric cannula was implanted in each pup at 4-6 d after birth (Hall, 1975). These pups were reared as described previously (Sonnenberg et al. 1982).

For experiments with RMS-2B, Sprague-Dawley rats were purchased from Bantin and Kingman, Fremont, CA and shipped to our facility on the 14th day of gestation. The rats were bred and reared in a specified-pathogen-free environment by the supplier and after arriving at our facility were maintained in an isolated area throughout the experiments. At the time of their arrival pregnant rats were housed in cages containing dust-free maize-cob 
bedding (Anderson's Cob Division, Delphi, IN). Whenever possible, genetic differences between litters were controlled for by weight-matching rat pups among litters and dividing them between the mother-reared (MR-B) control group and the experimental group reared on RMS-2B. The mother-reared groups consisting of eight to twelve rat pups per litter were weighed every $3 \mathrm{~d}$. The rat pups in the RMS-2B groups were each fitted with an intragastric cannula and reared on RMS-2B in the same manner as described for rats reared on RMS$2 \mathrm{~A}$.

\section{Assay of enzymes, metabolites and lipids}

Plasma samples were taken between 15 and $30 \mathrm{~min}$ following a feeding period in the artificially reared rats and without regard to the last suckling period in the mother-reared group. All enzymes, standards, cofactors and buffers were purchased from Sigma Chemical Co. All radiolabelled compounds were purchased from New England Nuclear, Boston, MA. The concentrations in plasma of acetoacetate, $D(-)$-3-hydroxybutyrate, carnitine, glucose, galactose, lactate and insulin, and the half-life $\left(T_{\frac{1}{2}}\right)$ and disposal rates for $\mathrm{D}(-)-3-$ hydroxybutyrate and glucose in blood were determined as previously described (Sonnenberg et al. 1982). Packed cell volumes were determined using an IEC model MB micro-haematocrit centrifuge (Damon IEC Division, Needham Heights, MA). The Coomassie blue method was used to determine the concentrations of protein in plasma and brain (Bradford, 1976). The enzymic activity of pyruvate dehydrogenase (EC 1.2.4.1) in brain was determined by the method of Ksiezak-Reding et al. (1982). The enzymic activity of 3-oxo-acid-CoA transferase (EC 2,8.3.5) in brain was measured by the method of Williamson et al. (1971) except that the incubation temperature for the assay was $37^{\circ}$. Acetoacetyl-CoA ligase activity $(E C 6.2 .1 .16)$ was measured by the radiochemical method described by Bergstrom \& Edmond (1985). The mass of cerebroside sulphate in brain was determined by the method of Kean (1968). The mass of sterols in brain was determined by gas-liquid chromatography as described by Bates \& Rothblat (1974).

\section{Respiration}

${ }^{14} \mathrm{CO}_{2}$ experiments. The ${ }^{14} \mathrm{CO}_{2}$ in the expired air was collected immediately after the subcutaneous injection of either $\mathrm{D}(-)-3$-hydroxy $\left[3-{ }^{14} \mathrm{C}\right]$ butyrate or $\left[2-{ }^{14} \mathrm{C}\right]$ glucose exactly as reported previously (Webber \& Edmond, 1977; Sonnenberg et al. 1982).

\section{Amino acid analyses}

Plasma samples from rats reared on RMS-2A were shipped on dry ice to AAA laboratories (Mercer Island, WA) and analysed for free amino acid concentrations. Each sample contained plasma pooled from three 16-d-old rat pups. Values are shown as means and standard deviations for each amino acid in three samples of plasma from the MR group and two samples of plasma from the RMS-2A group. The estimated error in measuring amino acid levels in plasma by AAA Laboratories was $5 \%$. Samples of deproteinized plasma from rats reared on RMS-2B were analysed for free amino acid content. Plasma $(0.07 \mathrm{ml})$ was deproteinized by adding an equal volume of ice-cold trichloracetic acid $(50$ $\mathrm{g} / \mathrm{l}$ ) and centrifuging at $120000 \mathrm{~g}$ (Beckman Airfuge, A-100 fixed angle rotor, Beckman Instruments Inc.) for 20 min at room temperature. Samples were prepared in duplicate for each rat and stored frozen at $-80^{\circ}$ until analysed for their amino acid content as described by Jones (1988). 
Table 2. Milk composition for rat's milk, premilks and rat milk-substitutes (RMS-2A and $R M S-2 B)$

(The values are from the analysis of the premilk bases and the milk substitutes constituted from them, as described on pp. 496-499)

\begin{tabular}{|c|c|c|c|c|c|c|}
\hline & \multirow[b]{2}{*}{ Rat's milk* } & \multirow[b]{2}{*}{ Premilk A } & \multirow[b]{2}{*}{ RMS-2A } & \multicolumn{2}{|c|}{ Premilk B } & \multirow[b]{2}{*}{ RMS-2B } \\
\hline & & & & $\begin{array}{l}\text { No whey } \\
\text { added }\end{array}$ & $\begin{array}{l}\text { With whey } \\
\text { added }\end{array}$ & \\
\hline \multicolumn{7}{|l|}{$\begin{array}{l}\text { Macronutrients } \\
\text { (g/1 milk) }\end{array}$} \\
\hline$n \dagger$ & - & 4 & 6 & 2 & 2 & 4 \\
\hline Fat & $93-175$ & $23-32$ & $96-120$ & $29-40$ & $26-33$ & $106-137$ \\
\hline Protein & $69-118$ & $83-98$ & $77-83$ & $93-110$ & $100-116$ & $90-117$ \\
\hline Casein & 6480 & nd & nd & 92 & 68 & $58-72$ \\
\hline Whey & $9 \cdot 2-25$ & nd & nd & 20 & 31 & $21-45$ \\
\hline $\begin{array}{l}\text { Carbohydrate } \\
\text { (total) }\end{array}$ & $28-37$ & $16-34$ & $24-50$ & $23-31$ & $6-8$ & $21-50$ \\
\hline Lactose & $11 \cdot 3-41$ & $4-17$ & $14-30$ & $7-17$ & $9-10$ & $17-24$ \\
\hline Ash & $13-15$ & $7-9$ & $11-16$ & $8-16$ & $9-10$ & $16-20$ \\
\hline \multicolumn{7}{|l|}{$\begin{array}{l}\text { Minerals } \\
\text { (mg/1 milk) }\end{array}$} \\
\hline$n+$ & - & 2 & 1 & 1 & 1 & 4 \\
\hline Calcium & $970-6200$ & $2800-2900$ & 3080 & 3140 & 2670 & $4200-5770$ \\
\hline Phosphorus & $1600-2720$ & $1550-1900$ & 2650 & 1610 & 1260 & $1990-3390$ \\
\hline Sodium & $660-1400$ & $110-230$ & 900 & 190 & 60 & $410-780$ \\
\hline Potassium & $1080-1700$ & $220-400$ & 2080 & 460 & 120 & $830-1290$ \\
\hline Chloride & $1170-1760$ & $270-400$ & 1200 & 490 & 310 & $1300-1560$ \\
\hline Magnesium & $0 \cdot 1-310$ & $180-200$ & 250 & 160 & 150 & $150-300$ \\
\hline Zinc & $9-55$ & $11-13$ & 13 & 14 & 22 & $18-30$ \\
\hline Iron & 4-7 & $3-4$ & 9 & 7 & 5 & $10-12$ \\
\hline Copper & $1 \cdot 7-7 \cdot 0$ & $0.4-0.7$ & 5 & $0 \cdot 3$ & $0 \cdot 3$ & $5 \cdot 5-7 \cdot 6$ \\
\hline $\begin{array}{l}\text { Energy content } \\
(\mathrm{kJ} / \mathrm{l} \text { milk }) \ddagger\end{array}$ & 5120.9200 & $2560-3420$ & $3520-6770$ & $3050-3460$ & $2890 \quad 3340$ & $5860-7970$ \\
\hline $\begin{array}{l}\text { Osmolarity } \\
\text { (mosm } / 1 \text { milk) }\end{array}$ & $352 \S$ & $80 \|$ & $318 \|$ & nd & $38 \|$ & $300-3769$ \\
\hline $\mathrm{pH}$ & $5 \cdot 7-6 \cdot 8$ & 6.8 & $6 \cdot 4$ & nd & nd & $6 \cdot 4$ \\
\hline
\end{tabular}

nd, not determined.

* Values for natural rat's milk are given as a range into which most reported values fall and were taken from Cox \& Mueller (1937), Luckey et al. (1954), Altman (1961), Glass et al. (1967), Miller \& Czajka (1967), Jenness \& Sloan (1970), Kuhn (1972), Chalk \& Bailey (1979), Keen et al. (1981).

$\uparrow$ Number of different milk preparations which were analysed. Milk preparations were analysed by Morning Star Laboratories, Los Angeles, CA and by Bioserv Inc., Frenchtown, NJ, as indicated on pp. 497 and 499 . All values given as a range were obtained from the number of analyses shown for each premilk or milk-substitute.

$\mp$ Energy content was calculated based on the following $(\mathrm{kJ} / \mathrm{g})$ : fat 37.6 , protein 16.9 , carbohydrate 16.9 .

$\S$ Value taken from Miller \& Czajka (1967).

$\|$ Analysed by UCLA Hospital Clinics.

T Range of values obtained in three analyses by UCLA Hospital Clinics and three analyses on a Wescor Inc. 5100 Vapor Pressure Osmometer.

\section{RESULTS}

\section{Composition of rat milk-substitutes}

Detailed analyses of the nutrient composition of the premilk formulas and the rat milksubstitutes, prepared from the components listed in Table 1, are shown in Table 2 . Both premilk-A and premilk-B contained a sufficient amount of protein when compared with values for protein reported for rat milk (Luckey et al. 1954; Altman, 1961; Dymsza et al. 
Table 3. Amino acid content of milk protein ( $\mathrm{mg} / \mathrm{g}$ protein) from rat's milk and rat milksubstitute RMS-2B prepared with and without whey*

\begin{tabular}{|c|c|c|c|c|}
\hline \multirow[b]{2}{*}{ Amino acid } & \multicolumn{2}{|c|}{ Rat's milk } & \multicolumn{2}{|c|}{$\mathrm{RMS}-2 \mathrm{~B} \dagger$} \\
\hline & At & $\mathrm{B} \S$ & With whey & Without whey \\
\hline Arginine & 34 & 26 & 34 & 33 \\
\hline Histidine & 25 & 26 & 35 & 37 \\
\hline Isoleucine & 47 & 51 & 51 & 48 \\
\hline Leucine & 55 & 100 & 86 & 86 \\
\hline Lysine & 53 & 56 & 84 & 82 \\
\hline Methionine & 19 & 25 & 13 & 10 \\
\hline Phenylalanine & 38 & 36 & 51 & 50 \\
\hline Threonine & 45 & 36 & 37 & 34 \\
\hline Tryptophan & 46 & 11 & 6 & 6 \\
\hline Valine & 50 & 55 & 68 & 64 \\
\hline Alanine & nd & 51 & 28 & 26 \\
\hline Asparagine + aspartic acid & 58 & 72 & 66 & 64 \\
\hline Cysteine & 40 & 8 & 5 & 5 \\
\hline Glutamine + glutamic acid & 202 & 230 & 228 & 203 \\
\hline Glycine & 17 & 11 & 22 & 23 \\
\hline Proline & 78 & 69 & 84 & 83 \\
\hline Serine & nd & 84 & 48 & 50 \\
\hline Tyrosine & 38 & 41 & 64 & 61 \\
\hline
\end{tabular}

nd, not determined.

* For details of composition, see Tables 1 and 2.

$\dagger$ Analysed by Bioserv Inc., Frenchtown, N.J.

\$ From Luckey et al. (1954) for total protein preparation (dialyzed acetone precipitated).

$\S$ From Woodward \& Messer (1976) for casein (protein material precipitated from rat's milk at $\mathrm{pH} 4.0$ ).

1964; Glass et al. 1967; Miller \& Czajka, 1967; Jenness \& Sloan, 1970; Chalk \& Bailey, 1979; Keen et al. 1981); these premilks were deficient in fat, carbohydrate and ash, when compared with the nutrient content reported for rat milk. The rat milk-substitutes, RMS$2 \mathrm{~A}$ and RMS-2B, were similar to rat's milk in composition (Table 2).

The relative concentrations of each of the amino acids in protein in RMS-2B, prepared with and without the addition of isolated whey protein, are shown in Table 3 . The concentrations of methionine, tryptophan, alanine, cysteine and serine were less than $65 \%$ of the lower value reported for casein or protein from rat's milk. Lysine, phenylalanine, glycine and tyrosine in the rat milk-substitute were in excess by $30-50 \%$ of the higher values for casein or protein from rat's milk.

A detailed summary of the distribution of individual fatty acids in the fat component of the rat milk-substitutes is shown in Table 4. RMS-2A contained a greater proportion of the total fatty acids as octanoic acid (8:0), and less as lauric acid $(12: 0)$ than RMS-2B or rat's milk (Altman, 1961). Both RMS-2A and RMS-2B contained less myristic (14:0), palmitic $(16: 0)$ and palmitoleic $(16: 1)$ acids, and more linoleic $(18: 2)$ acid in their fat than rat's milk.

\section{Growth and survival}

$R M S-2 A$-reared rats. Growth rates as determined by body-weight measurements were not different in rat pups reared by their mothers and those reared on RMS-2A according to the feeding schedule shown in Fig. $1(a, b)$. The mortality of the artificially reared rat pups was approximately $20-25 \%$; approximately $5-10 \%$ developed bloat (a condition of gastric distention; Tonkiss et al. 1985) and 10-20\% showed signs of respiratory illness. The mortality rate of MR-A pups was zero. 
Table 4. Fatty acid composition of fat (weight $\%$ total fatty acids) in rat's milk and rat milk-substitutes $R M S-2 A$ and $R M S-2 B^{*}$

\begin{tabular}{cccc}
\hline \hline Fatty acid & Rat's milk $\dagger$ & RMS-2A $\$$ & RMS-2B $\ddagger$ \\
\hline $8: 0$ & $2 \cdot 5-6 \cdot 5$ & $20 \cdot 3$ & $5 \cdot 6$ \\
$10: 0$ & $8 \cdot 7-17 \cdot 4$ & $11 \cdot 0$ & $14 \cdot 8$ \\
$12: 0$ & $9 \cdot 5-12 \cdot 6$ & $1 \cdot 3$ & $13 \cdot 7$ \\
$14: 0$ & $9 \cdot 2-14 \cdot 3$ & $3 \cdot 0$ & $2 \cdot 5$ \\
$16: 0$ & $18 \cdot 4-32 \cdot 6$ & $12 \cdot 9$ & $11 \cdot 5$ \\
$16: 1$ & $1 \cdot 8-2 \cdot 3$ & $0 \cdot 6$ & $0 \cdot 8$ \\
$18: 0$ & $2 \cdot 4-4 \cdot 2$ & $4 \cdot 6$ & $4 \cdot 4$ \\
$18: 1$ & $15 \cdot 2-20 \cdot 4$ & 18.7 & 16.9 \\
$18: 2$ & $6 \cdot 0-11 \cdot 4$ & $26 \cdot 1$ & $27 \cdot 9$ \\
$18: 3$ & $0 \cdot 6-1 \cdot 3$ & $0 \cdot 5$ & $1 \cdot 8$ \\
\hline \hline
\end{tabular}

* For details of composition, see Tables 1 and 2.

$\dagger$ The range of values in natural rat's milk reported by Glass et al. (1967); Smith et al. (1968); Brandorff (1980).

* Analysed in duplicate by Bioserv Inc., Frenchtown, NJ.
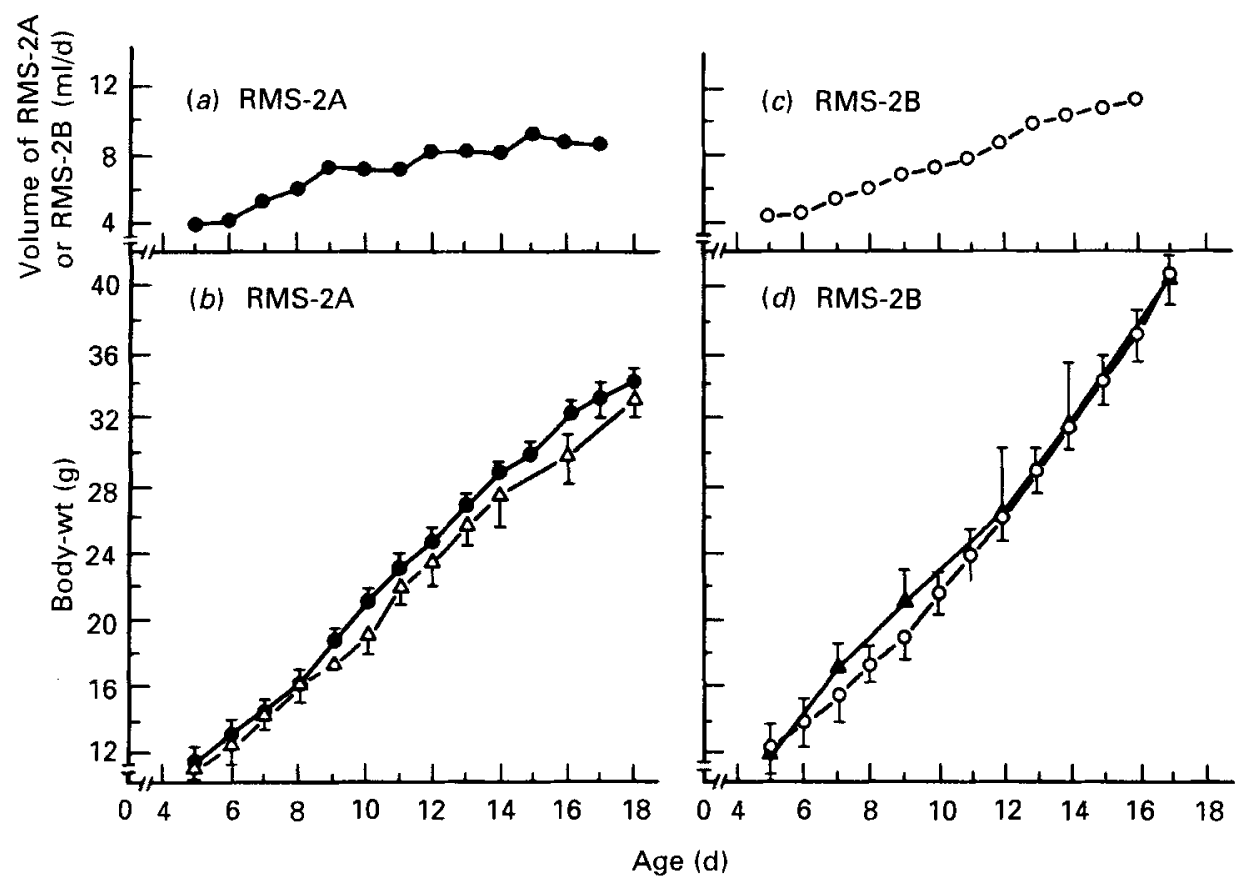

Fig. 1. Milk volume given $(a, c)$ and growth in body-weight $(b, d)$ of rat pups artificially reared on rat milk-substitutes RMS-2A $(a, b)$ and RMS-2B $(c, d)$ infused over the subsequent $24 \mathrm{~h}$ period as described by Sonnenberg et al. (1982). RMS-2A was infused for a period of $10 \mathrm{~min} / \mathrm{h}$ from day 5 to day 18 . RMS$2 \mathrm{~B}$ was infused for a period of $10 \mathrm{~min}$ from day 5 to day 10 , then infused for a period of $20 \mathrm{~min} / \mathrm{h}$ from day 10 to day 17. (b) Mean body-weight ( $\mathrm{g}$ ) from 5 to $18 \mathrm{~d}$ of age for rat pups artificially reared on RMS$2 \mathrm{~A}(\odot), n 8$, and their mother-reared controls (MR-A) $(\triangle), n 10 .(d)$ Mean body-weight $(\mathrm{g})$ from 5 to $17 \mathrm{~d}$ of age for rat pups artificially reared on RMS-2B $(O), n 8$, and their mother-reared controls (MRB) (A), $n$ 10. The values are means and standard deviations represented by vertical bars. For details of the dietary regimens and procedure for rearing, see pp. 499 and 501. 


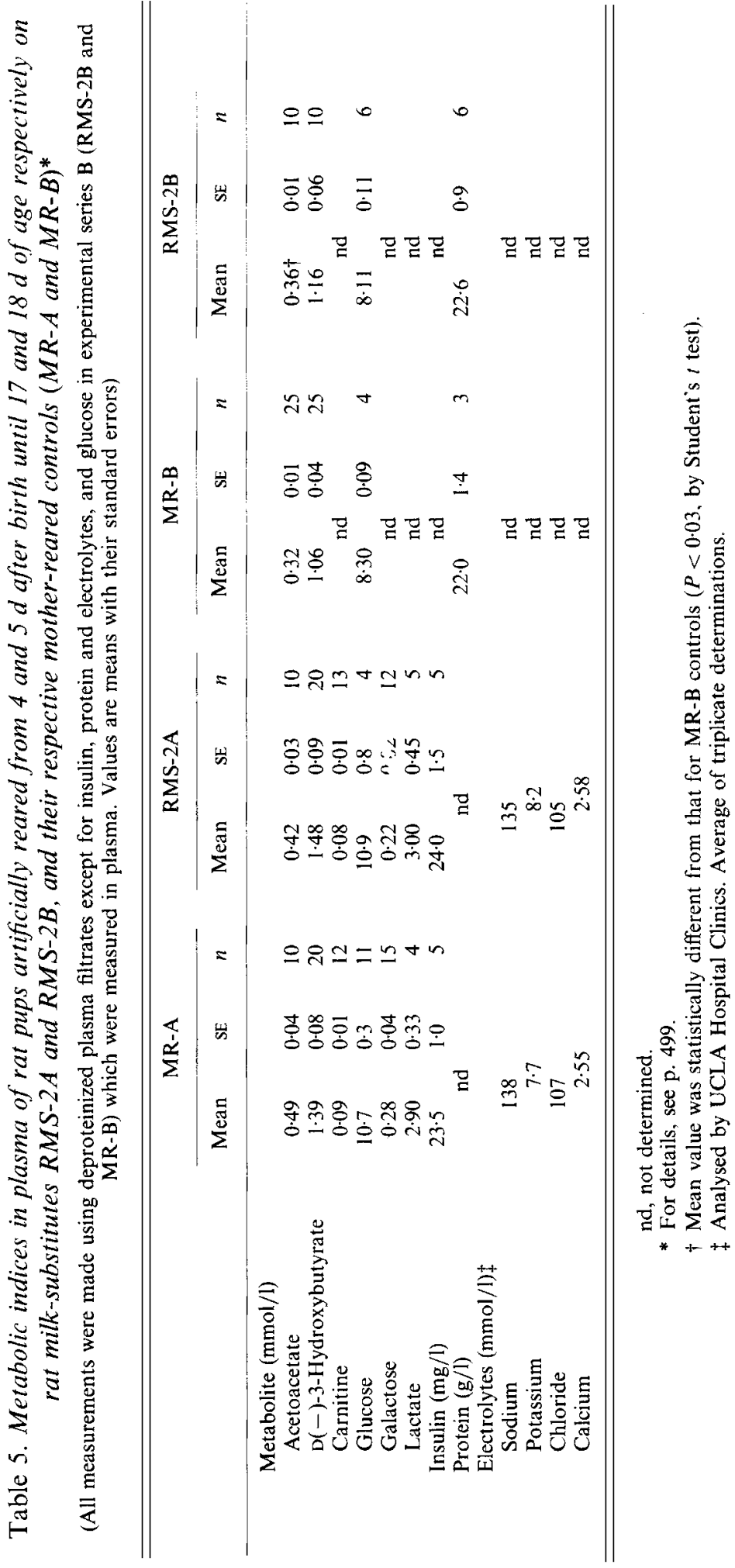


Table 6. Turnover $\left(\mathrm{T}_{\frac{1}{2}}\right)$ of blood $D(-)$-3-hydroxybutyrate and glucose in rat pups reared on rat milk-substitute RMS-2A and in their mother-rearea controls $(M R-A)^{*}$

(Values shown are part of the experiments presented in Table 5)

\begin{tabular}{lcc}
\hline \hline & MR-A & RMS-2A \\
\hline $\mathrm{D}(-)$-3-Hydroxybutyrate (mmol/1 plasma filtrate) & & $1 \cdot 48$ \\
Mean & $1 \cdot 39$ & $0 \cdot 09$ \\
SE & $0 \cdot 08$ & $8 \cdot 0$ \\
$T_{\frac{1}{2}}(\mathrm{~min}) \dagger$ & $8 \cdot 8$ & $0 \cdot 12$ \\
Rate of disposal (mmol/min per 1 plasma filtrate) $\dagger$ & $0 \cdot 15$ & \\
Glucose (mmol/1 plasma filtrate) & & $10 \cdot 9$ \\
Mean & $10 \cdot 7$ & $0 \cdot 8$ \\
SE & $0 \cdot 3$ & 25 \\
$T_{\frac{1}{2}}$ (min) $\dagger$ & 31 & $0 \cdot 30$ \\
Rate of disposal (mmol/min per 1 plasma filtrate) $\dagger$ & $0 \cdot 25$ & \\
\hline \hline
\end{tabular}

* For details, see p. 500 .

$\dagger$ Average of values from two separate experiments performed as described by Webber \& Edmond (1979), Sonnenberg et al. (1982).

$R M S-2 B$-reared rats. Growth rates as determined by body-weight measurements were not different in rat pups reared by their mother and those reared on RMS-2B according to the feeding schedule specified in Fig. $1(c, d)$. The mortality of the RMS-2B-reared rat pups was low, approximately $3-5 \%$, and the result of technical problems associated with the rearing system, principally the leaking of cannulas which could not be corrected. Respiratory illness was not evident and the incidence of bloat was minimal. The mortality rate of MR-B controls was zero. Although Sprague-Dawley rats were studied in all the experiments, the rats reared on RMS-2B and the MR-B controls (obtained from Bantin and Kingman) exhibited faster growth rates than those reared on RMS- $2 A$ and the MRA controls (Fig. 1).

During the first 3-5 d after being fitted with the intragastric cannula, the artificially reared rat pups grew at a slightly slower rate than the mother-reared pups regardless of the amount of milk infused. At about $10 \mathrm{~d}$ of age, they caught up in weight to that of motherreared pups and their growth rates could then be matched to those of the mother-reared group by adjusting the infusion rate of the milk. Similar observations have been reported previously (West et al. 1982; Smart et al. 1984).

\section{Status of metabolism}

A comparison among the artificially reared and mother-reared groups of plasma concentrations of key metabolites, protein and electrolytes is shown in Table 5.

RMS-2A-reared rats. The concentrations of the ketone bodies, acetoacetate and 3hydroxybutyrate, and of carnitine, an important cofactor in fatty acid metabolism, in the plasma filtrates of the RMS-2A group were not different from those of the MR-A control group. The concentrations of insulin and the major products of carbohydrate metabolism, i.e. glucose, galactose and lactate, in plasma filtrates of the RMS-2A group were also not different from the MR-A group. The concentrations in plasma of $\mathrm{Na}, \mathrm{K}, \mathrm{Cl}, \mathrm{Ca}$ were compared and also found to be normal in the rats reared on the RMS-2A.

Rates for the turnover in blood of the ketone body, $D(-)$-3-hydroxybutyrate, and of glucose as expressed by $T_{\frac{1}{2}}$ and their rates of disposal from blood in 16-d-old rat pups were not different in the MR-A and RMS-2A groups (Table 6) from the range in values reported by Vernon \& Walker (1972) and Webber \& Edmond (1979). 


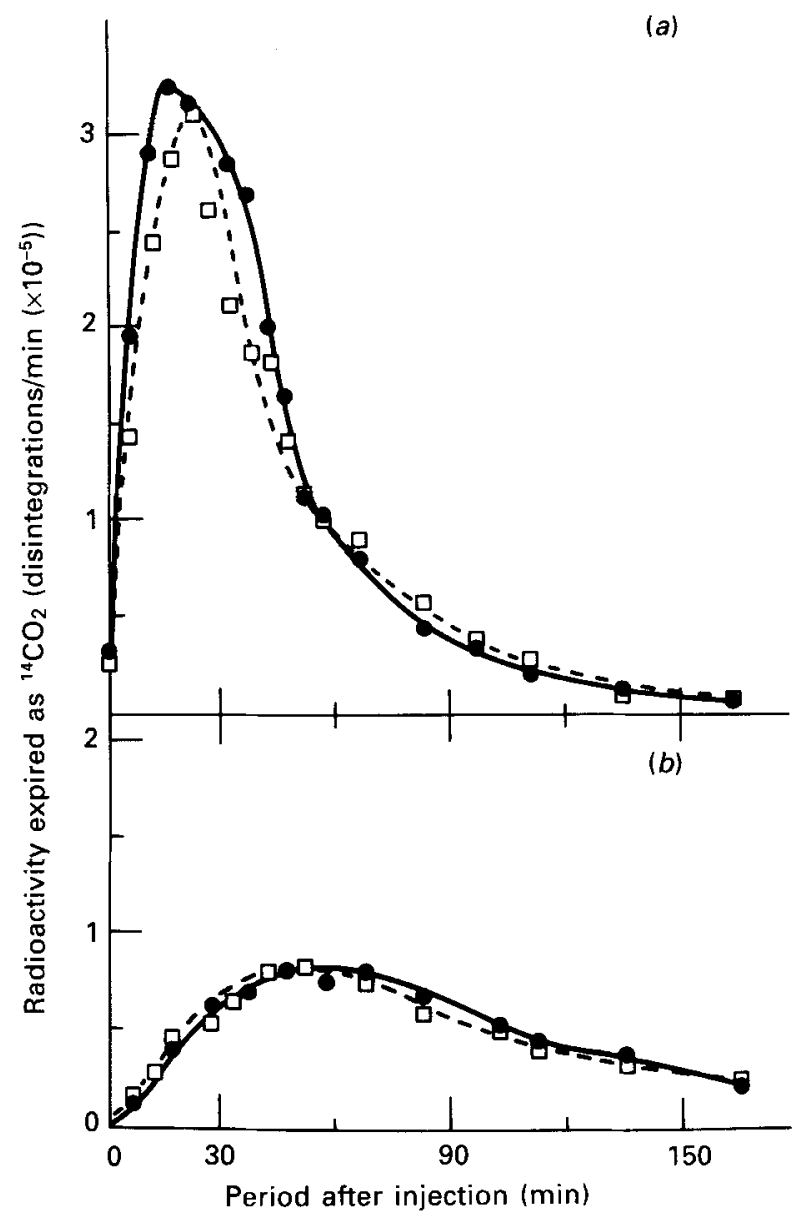

Fig. 2. Respiration as measured by the production of expired ${ }^{14} \mathrm{CO}_{2}$ after the subcutaneous injection of either $(a) \mathrm{D}(-)$-3-hydroxy $\left[3-{ }^{14} \mathrm{C}\right]$ butyrate or $(b)\left[2-{ }^{14} \mathrm{C}\right] \mathrm{glucose}$ for rat pups reared on rat milk-substitute RMS-2A $(\square-\cdots)$, and for mother-reared controls $(--)$ ); for details of the dietary regimens and procedure for rearing, see pp. 499 and 501. After injection each rat was placed immediately in a respiration chamber and expired $\mathrm{CO}_{2}$ was collected and quantified as described on p. 500. Experiments were done in duplicate and the values for each time point were averaged; variability was less than $10 \%$ of the average at each time-point. The values are plotted at the midpoint of each time-interval for collection after the injection of labelled substrate, as described by Webber \& Edmond (1979) and Sonnenberg et al. (1982).

$R M S-2 B$-reared rats. The concentrations of glucose and protein in plasma and of $\mathrm{D}(-)$ 3-hydroxybutyrate in plasma filtrates in the RMS-2B-reared group were not different from those in the mother-reared group (Table 5). The concentration of acetoacetate in plasma filtrates from RMS-2B-reared pups was statistically higher than that in plasma filtrates from MR controls $(P<0.03)$. The concentration of acetoacetate in plasma of these rat pups was in the range reported by Page et al. (1971) for rat pups at means (SD) of $0.45(0.11)$ $\mathrm{mmol} / 1$ and $0.36(0.06) \mathrm{mmol} / 1$ in the age ranges $11-15 \mathrm{~d}$ and $16-20 \mathrm{~d}$ respectively.

Respiration. The amount of label expired as ${ }^{14} \mathrm{CO}_{2}$ during a given time-period after the subcutaneous injection of $10 \mu \mathrm{Ci}$ of a labelled substrate gives an indication of the availability of that substrate for respiration (Webber \& Edmond, 1977). As shown in Fig. 2 , the profiles for the expiration of ${ }^{14} \mathrm{CO}_{2} / \mathrm{min}$ over a $3 \mathrm{~h}$ period for the mother-reared 
Table 7. Amino acids in plasma (umol/l) from rat pups artificially reared on rat milksubstitute $R M S-2 A$, and in their mother-reared controls $(M R-A)^{*}$

(To obtain sufficient volume for analyses, plasma samples from three pups were combined to provide the number of samples analysed. Values are means and standard deviations)

\begin{tabular}{|c|c|c|c|c|}
\hline & \multicolumn{2}{|c|}{ MR-A } & \multicolumn{2}{|c|}{ RMS-2A } \\
\hline & Mean & SD & Mean & SD \\
\hline$n$ & \multicolumn{2}{|c|}{3} & \multicolumn{2}{|c|}{2} \\
\hline Histidine & 161 & 10 & 140 & 2 \\
\hline Isoleucine & 122 & 14 & 188 & 32 \\
\hline Leucine & 272 & 87 & 328 & 39 \\
\hline Lysine & 800 & 54 & 1283 & 173 \\
\hline Methionine & 96 & 24 & 188 & 48 \\
\hline Phenylalanine & 137 & 40 & 146 & 8 \\
\hline Threonine & 423 & 34 & 514 & 25 \\
\hline Tryptophan & nd & - & nd & - \\
\hline Valine & 290 & 38 & 415 & 44 \\
\hline Tyrosine & 267 & 45 & 343 & 22 \\
\hline Alanine & 541 & 43 & 598 & 27 \\
\hline Arginine & 378 & 19 & 547 & 243 \\
\hline Asparagine & 73 & 3 & 95 & 19 \\
\hline Aspartate & 72 & 3 & 70 & 8 \\
\hline Glutamate & 163 & 12 & 168 & 4 \\
\hline Glutamine & 780 & 223 & 1010 & 78 \\
\hline Glycine & $42 I$ & 88 & 328 & 13 \\
\hline Ornithine & 209 & 17 & 213 & 37 \\
\hline Proline & 440 & 14 & 869 & 40 \\
\hline Serine & 494 & 43 & 436 & 23 \\
\hline Citrulline & 193 & 17 & 257 & 23 \\
\hline Taurine & 214 & 47 & 130 & 38 \\
\hline
\end{tabular}

nd, not determined by the method.

* For details, see p. 500 .

group were not different from that for the RMS-2A group after the subcutaneous injection of either $10 \mu \mathrm{Ci} \mathrm{D}(-)$-3-hydroxy[3- $\left.{ }^{14} \mathrm{C}\right]$ butyrate (Fig. $2(a)$ ) or $\left[2-{ }^{14} \mathrm{C}\right] g l u c o s e$ (Fig. $2(b)$ ).

\section{Amino acids}

$R M S$-2A-reared rats. The concentrations of most of the amino acids in the plasma of rats reared on RMS-2A were similar to those in plasma of their mother-reared controls (Table 7). Isoleucine, lysine, methionine and proline were 1.5 to 2 -fold higher in the plasma of the RMS-2A-reared rats than of the MR-A (mother-reared) group within a short period after feeding.

$R M S-2 B$-reared rats. The mean concentrations of the essential amino acids and most of the non-essential amino acids in the plasma of the MR-B control group at $3 \mathrm{~h}$ after feeding when the stomachs were nearly empty were not different from those values obtained when the stomachs contained an ample supply of milk (at approximately $20 \mathrm{~min}$ after the rat pups were observed feeding) (Table 8). By contrast, the mean concentrations of most of the essential amino acids and many of the non-essential amino acids in the RMS-2B-reared rats at $3 \mathrm{~h}$ after feeding were substantially lower than at $20 \mathrm{~min}$ after the feeding period (Table 8). The mean concentrations of most of the essential amino acids in the plasma of rats reared on RMS-2B were 1.4- to 3-fold higher than that of their mother-reared controls during the early post-prandial period (Table 8). Arginine, aspartic acid and citrulline were 


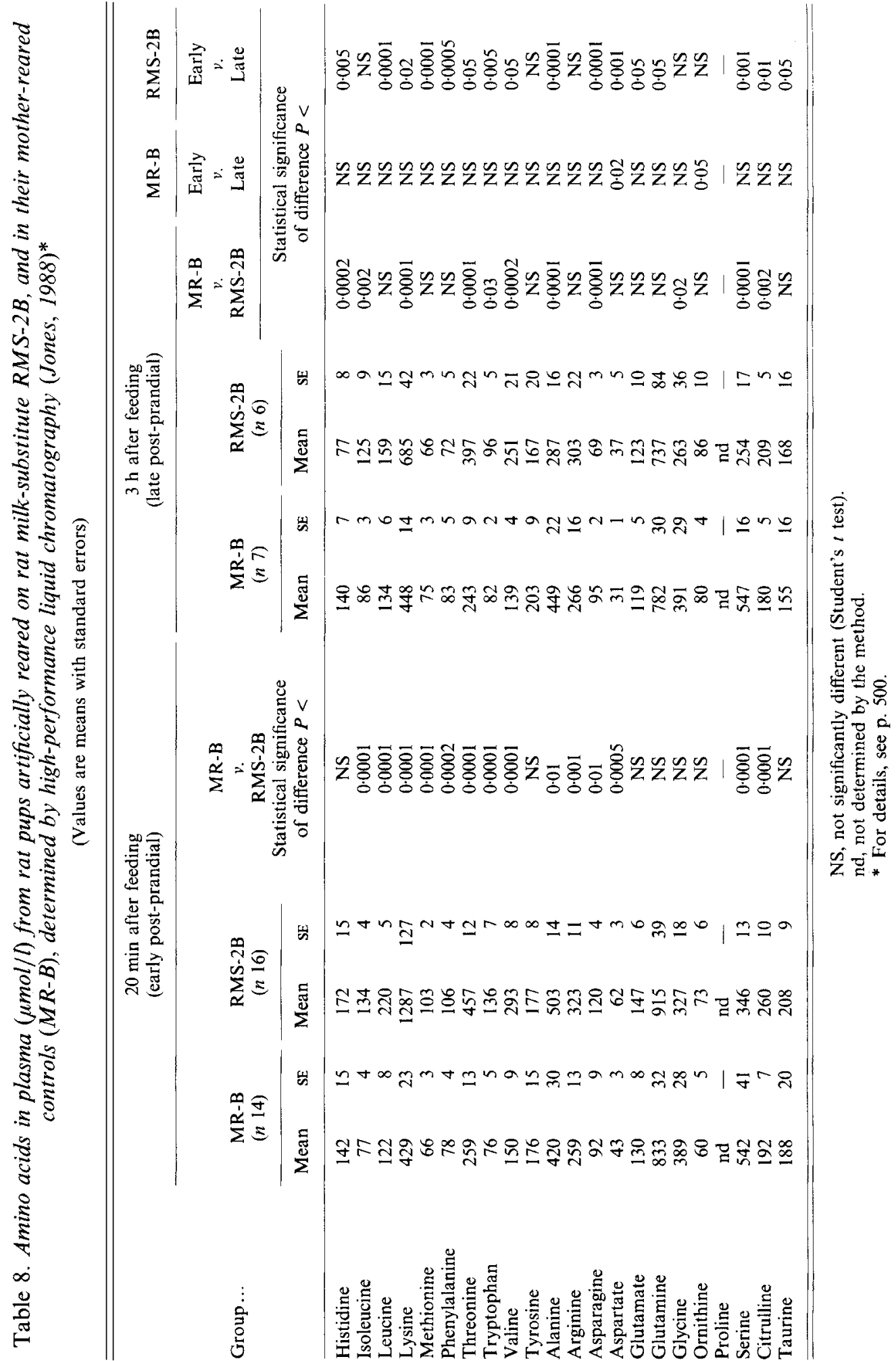


Table 9. Developmental indices in brain from rat pups artificially reared on rat milksubstitutes RMS-2A or RMS-2B, and in their mother-reared controls ( $M R-A$ and $M R-B$ respectively)*

\begin{tabular}{|c|c|c|c|c|c|c|}
\hline & \multicolumn{3}{|c|}{ MR-A } & \multicolumn{3}{|c|}{ RMS-2A } \\
\hline & Mean & $\mathrm{SE}$ & $n$ & Mean & SE & $n$ \\
\hline \multicolumn{7}{|l|}{$\begin{array}{l}\text { Pyruvate dehydrogenase }(E C \quad 1.2 .4 .1) \\
\text { (nmol/min per mg protein) }\end{array}$} \\
\hline $12 \mathrm{~d}$ of age & $31 \cdot 3$ & $1 \cdot 3$ & 5 & $34 \cdot 7$ & $1 \cdot 0$ & 3 \\
\hline \multirow[t]{3}{*}{$16 \mathrm{~d}$ of age } & $48 \cdot 3$ & 0.6 & 10 & $45 \cdot 9$ & $3 \cdot 4$ & 5 \\
\hline & \multicolumn{3}{|c|}{ MR-B } & \multicolumn{3}{|c|}{ RMS-2B } \\
\hline & Mean & $\mathrm{SE}$ & $n$ & Mean & $\mathrm{SE}$ & $n$ \\
\hline Brain wt $(g)$ & $1 \cdot 37$ & 0.01 & 24 & $1.27 \dagger$ & 0.01 & 32 \\
\hline Protein (mg/g brain) & $73 \cdot 3$ & 0.8 & 21 & $73 \cdot 6$ & 0.5 & 31 \\
\hline $\begin{array}{l}\text { 3-Oxo-acid-CoA transferase (EC 2.8.3.5) } \\
\text { ( } \mu \mathrm{mol} / \mathrm{min} \text { per mg protein) }\end{array}$ & 0.79 & 0.02 & 14 & 0.81 & 0.02 & 28 \\
\hline $\begin{array}{l}\text { Acetoacetyl-CoA ligase }(E C 6.2 .1 .16) \\
\text { (nmol/min per mg protein) }\end{array}$ & $7 \cdot 7$ & $2 \cdot 9$ & 5 & $7 \cdot 1$ & $2 \cdot 3$ & 5 \\
\hline Cholesterol (mg/g brain) & $8 \cdot 88$ & 0.29 & 4 & 8.95 & $0 \cdot 30$ & 4 \\
\hline Cerebroside-sulphate ( $\mu \mathrm{mol} / \mathrm{g}$ brain) & $1 \cdot 20$ & 0.05 & 15 & $1 \cdot 17$ & 0.03 & 21 \\
\hline
\end{tabular}

* For details, see p. 500.

$\dagger$ Mean value was statistically different from that for MR-B controls ( $P<0.005$, by Student's $t$ test).

also 1.2- to 1.4-fold higher in plasma of rats reared on RMS-2B than that of their MR-2B (mother-reared) controls during this period. By $3 \mathrm{~h}$ after a feeding period, most of the amino acids in the plasma of rats from the RMS-2B group were at concentrations which were not different from those from the MR-B group. Although the amounts of isoleucine, lysine, threonine, valine and citrulline in plasma of the RMS-2B group had also decreased by $3 \mathrm{~h}$ after feeding, they continued to be at concentrations statistically higher than their MR-B controls. Surprisingly, the concentration of serine in plasma of the RMS-2B group was $0.5-0.6$ times that in the MR-B control group at both the early ( $20 \mathrm{~min})$ and late (3 h) post-prandial periods. Both alanine and asparagine were also at concentrations in plasma of the RMS-2B group that were $0.6-0.7$ times that in the MR-B control group at $3 \mathrm{~h}$ after feeding.

\section{Developmental indices in the brain}

The enzymic activity of pyruvate dehydrogenase in brain was compared in rat pups reared with their mother and those reared on RMS-2A and was not different at 12 and $16 \mathrm{~d}$ of age (Table 9).

Important brain components of rats reared on RMS-2B and MR-B rats of equivalent age and weight are also shown in Table 9. Total protein concentration, the activities of two ketone-body-utilizing enzymes, acetoacetyl-CoA ligase and 3-oxo-acid-CoA transferase, and the concentrations of cholesterol and cerebroside sulphate in the artificially reared group were not different from those in the MR group. However, brain weights in the rat pups reared on the milk-substitute RMS- 2 B were $93 \%(P \leqslant 0.005)$ of those in the MR-B control group. 


\section{Developmental indices of the gastrointestinal tract}

In our studies with RMS-2A-reared rats we observed that the consistency of the stomach contents was coarser and more granular than that for rat pups of equivalent age reared with their mother. The consistency of the stomach contents of rats reared on RMS-2B more closely resembled that of rat pups reared with their mother.

The weights of the stomach (minus contents) and the lengths of the small intestines from rat pups reared on RMS-2B ( $n$ 10) were compared with those of their MR-B controls ( $n$ 10) of equivalent body-weights, means 40.3 (SD 2.9) and 40.6 (SD 1.4) g respectively. The stomach weights of the RMS-2B-reared rats were not different from those of their MR-B controls, mean 0.25 (SD 0.01) $\mathrm{g}$ and mean 0.23 (SD 0.03) g respectively. The small intestines in the RMS-2B-reared rats were $10 \%$ longer than the small intestines of MR-B controls, mean 579 (SD 34) $\mathrm{mm}$ and mean 514 (SD 21) mm respectively $(P<0.001)$.

\section{DISCUSSION}

\section{General}

The collective efforts of a number of investigators in developing the artificial rearing system (Messer et al. 1969; Hall, 1975; Diaz et al. 1982; Tonkiss et al. 1985) have made it possible to begin to examine nutrient requirements during the neonatal period in the rat. One of the limitations in using the artificial rearing system for this purpose has been that commercially available milk products differ substantially in composition from rat's milk. Several procedures to modify cow's milk (Dymsza et al. 1964; Thoman \& Arnold, 1967; Messer et al. 1969; Diaz et al. 1982) or human infant formula (Kris-Etherton et al. 1979) for the artificial rearing of rat pups have been described; some mimic rat's milk in the concentration of the macronutrients but are inadequate in promoting normal growth (Dymsza et al. 1964; Kris-Etherton et al. 1979). Other formulations are deficient in protein (Thoman \& Arnold, 1967; Messer et al. 1969) or contain excessive quantities of lactose (Thoman \& Arnold, 1967; Diaz et al. 1982), or both. Previous studies in our laboratory demonstrated that the metabolic status of rat pups reared on the formula developed by Messer et al. (1969), named RMS-1 by Sonnenberg et al. (1982) and referred to as CMF by Yeh (1983) or milk M by Tonkiss et al. (1985) was abnormal compared with the metabolic status of mother-reared rats, apparently reflecting metabolic adjustments to the differences in the macronutrient content of this diet compared with rat's milk (Sonnenberg et al. 1982). Other metabolic anomalies could not be related directly to the composition of RMS-1 (Sonnenberg et al. 1982).

We initially attempted to prepare a rat milk-substitute by mixing casein hydrolysate, lactose, maize oil, soya-bean oil, vitamins and minerals in water to approximate the composition of rat's milk. The casein hydrolysate was not soluble at $90 \mathrm{~g} / 1$ and the osmolarity was excessive as detailed by Miller \& Czajka (1967), so this approach was abandoned. We then developed the procedure to reduce the concentration of lactose in commercially available milk, producing a soluble protein-rich milk base to which appropriate quantities of other constituents could be added.

\section{Composition of milks}

The concentrations of fat, protein, carbohydrate and individual minerals and vitamins in RMS-2A and RMS-2B are similar to those of rat's milk; however, values reported for the concentrations of fat, protein and several minerals in rat's milk differ considerably (Luckey et al. 1954; Altman, 1961 ; Dymsza et al. 1964; Glass et al. 1967; Smith et al. 1968; Jenness \& Sloan, 1970; Rassin et al. 1978; Chalk \& Bailey, 1979; Brandorff, 1980; Grigor \& 
Warren, 1980; Keen et al. 1981). There are characteristic differences in the nutrient content of milk among strains of rats (Luckey et al. 1954; Chalk \& Bailey, 1979; Godbole et al. 1981; Keen et al. 1981), particularly for changes in the lactose and fat content of the milk during the lactation period. Keen et al. (1981) report that there are unique changes in the concentrations of protein, carbohydrate, $\mathrm{Ca}, \mathrm{Fe}, \mathrm{Cu}, \mathrm{Zn}$ and $\mathrm{Mg}$ in rat's milk from Sprague-Dawley rats during the lactation period. However, most of these changes occur in the early or the late lactation period and not during the mid-lactation period when rat pups are reared artificially on milk-substitutes (Messer et al. 1969; Hall, 1975; Diaz et al. 1982; Sonnenberg et al. 1982; West et al. 1982; Smart et al. 1984; Tonkiss et al. 1985). Whenever possible we have attempted to mimic the composition of rat's milk as reported most recently by Keen et al. (1981) for Sprague-Dawley rats, the strain used in our studies. Other factors that could contribute to the reported differences in the concentration of these nutrients by different investigators include not only the time phase of the lactation period and the number of lactation periods, but whether milkings were done at regular intervals or whether each milking was complete (Hytten, 1954; Bailey et al. 1955; Chalk \& Bailey, 1979; Forsum \& Lonnerdal, 1979; Smart et al. 1987).

Particular attention was given to maintaining the osmolarity of these rat milk-substitutes at a value similar to that of rat's milk to reduce the potential for abdominal distention and increased mortality (Miller \& Czajka, 1967).

Fat, protein and carbohydrate. A significant proportion, $21-37 \%$ by weight, of the total fatty acids in fat in rat's milk are medium-chain length fatty acids, with $30-51 \%$ by weight long-chain saturated fatty acids (LCSFA) and 24-35\% by weight long-chain unsaturated fatty acids (LCUFA) (Glass et al. 1967; Smith et al. 1968; Chalk \& Bailey, 1979; Brandorff, 1980). In RMS-2A the fat component is a combination of fat from the cow's-milk base, medium-chain triglycerides (MCT), maize oil and safflower oil. The fat component of RMS-2B is a modification of that in RMS-2A and better approximates that in rat's milk. In addition to the oils added to RMS-2A, Captex, a custom-synthesized MCT mixture, has been added, soya-bean oil was substituted for safflower oil and the amounts of the oils added were adjusted. The metabolic consequences of the lower LCSFA : LCUFA value in both rat milk-substitutes have not been evaluated. One of the limitations of these rat milksubstitutes is that the fluidity of the milk must be considered, and subtle changes in the method of preparation can result in a milk-substitute of such viscosity that it does not readily flow through the intragastric cannula. This was our experience when we increased the LCSFA using tripalmitin.

Appropriate concentrations of protein and carbohydrate were obtained by dialysis and concentration of cow's milk. Casein : whey ratio in RMS-2A is similar to that in cow's milk (Woodward \& Messer, 1976), while this ratio in RMS-2B is similar to that in rat's milk. We were readily able to introduce whey into the preparation of RMS-2B by applying the Amicon DC10L concentrator-dialyzer.

The amino acid profile for RMS-2B was not affected by the addition of isolated whey protein to the preparation (Table 3). In the preparation of RMS-2B as well as RMS-2A, arginine, glycine and taurine were added to the premilk base. The supplemental amounts of these amino acids were determined experimentally in our studies with RMS-2A; the concentrations of these amino acids were adjusted in RMS-2A until the concentrations of the individual amino acids in the blood of 16-d-old rat pups reared on RMS-2A were in line with their respective concentrations in the blood of mother-reared rat pups.

The concentration of lactose was substantially reduced in the premilk bases for both RMS-2A and RMS-2B and was thus added in appropriate quantities in the preparation of these rat milk-substitutes. The availability of a rat milk-substitute depleted of lactose has been essential for studies designed to understand developmental activity of gastrointestinal 
disaccharidases by Goda et al. $(1985 a, b)$. In these studies neonatal rats were intubated with RMS-2A modified only by the addition of the disaccharide of interest rather than lactose.

Minerals and vitamins. We have formulated specific mineral and vitamin mixtures which were added to the premilk base as specified in Table 1 to bring individual minerals and vitamins to near-normal levels in RMS-2. Three different ranges for $\mathrm{Ca}$ concentration in rat's milk have been reported : $970-1030 \mathrm{mg} / \mathrm{l}$ (Keen et al. 1981), 2680-3840 mg/l (Luckey et al. 1954), and $6200 \mathrm{mg} / \mathrm{l}$ (Dymsza et al. 1964). The relatively high concentration of $\mathrm{Ca}$ compared with the other minerals in premilk-A and premilk-B suggests that $\mathrm{Ca}$ is bound to macromolecules in the protein fraction of the premilk base. We were concerned that the bioavailability of $\mathrm{Ca}$, presumably bound to protein macromolecules which originated in cow's milk, was not known. We added $\mathrm{Ca}$ as calcium carbonate to ensure that rat pups received an adequate quantity of $\mathrm{Ca}$ in a bioavailable form. It has been reported than in human beings no difference exists in the utilization of $\mathrm{Ca}$ as the gluconate, lactate, carbonate or sulphate salts (Patton \& Sutton, 1952). An appropriate $\mathrm{Ca}: \mathrm{P}$ value was maintained in the rat milk-substitutes. A Ca:P value of between 1.0 and 1.5 is recommended during the rapid growth period in the rat by the National Research Council (1978) of the National Academy of Sciences, Washington. Others report that a $\mathrm{Ca}: \mathbf{P}$ of 2.0 in animals maximizes $\mathrm{Ca}$ absorption and minimizes its loss from bone (Hegsted, 1973). Specific studies may be required to determine definitively the most appropriate form and concentration for $\mathrm{Ca}$ in the rat milk-substitutes.

Dymsza et al. (1964) report very low concentrations for $\mathrm{Mg}$ in rat's milk, $0 \cdot 1 \mathrm{mg} / \mathrm{l}$, compared with those reported by others, $158-195 \mathrm{mg} / 1$ (Keen et al. 1981) and 240-310 $\mathrm{mg} / \mathrm{l}$ (Luckey et al. 1954). Although $\mathrm{Mg}$ also appears to be bound in sufficient quantities to the protein fraction of the premilk base, $\mathrm{Mg}$ was added to the premilk base as magnesium sulphate for reasons analogous to those described previously for $\mathrm{Ca}$.

Spray (1950) reports a higher concentration for $\mathrm{Zn}$ in rat's milk, $55 \mathrm{mg} / \mathrm{l}$, than those reported by others, $10 \mathrm{mg} / 1$ (Dymsza et al. 1964) and 9-14 mg/1 (Jenness \& Sloan, 1970). RMS-2A contains only the $\mathrm{Zn}$ which is bound to macromolecules in the protein fraction of the premilk base A. The concentration of $\mathrm{Zn}$ in RMS-2B is approximately twofold higher than that in RMS-2A; zinc sulphate was added to RMS-2B to ensure that another form of $\mathrm{Zn}$ would be available.

Fe concentrations in rat milk have been reported at $6 \cdot 1 \mathrm{mg} / 1$ (Dymsza et al. 1964) and 4.2-5.3 mg/l (Lonnerdal et al. 1978; Keen et al. 1981). Intestinal absorption of Fe as the ferrous salt by neonatal rats has been shown to be $100 \%$ at doses up to $50 \mu \mathrm{g}$ (Ezekiel, 1967). It is not known if the Fe in the premilk available from the cow's-milk base at a concentration of $3.7 \mathrm{mg} / 1$ is absorbed well by the rat intestinal lumen. To ensure that rat pups receive an adequate supply of Fe we add $27 \mathrm{mg}$ hydrated ferrous sulphate $/ 1 \mathrm{milk}$. Packed cell volumes were determined as a crude measure of Fe status and were found to be normal when this amount was added, mean 0.274 (SE 0.004) for the mother-reared group ( $n$ 15) compared to mean 0.299 (SE 0.004) for the RMS-2B group ( $n$ 17).

Other components. Ascorbic acid is generally not considered an essential nutrient for the rat but was reported to be present in rat's milk at a concentration of $3.5-18 \mathrm{mg} / \mathrm{l}$ (Luckey et al. 1954); therefore we included it in our vitamin mixture. The concentration of carnitine in rat's milk is reported to be particularly high, $60 \mathrm{mg} / \mathrm{l}$, at birth, gradually decreasing to $20 \mathrm{mg} / 1$ at $8 \mathrm{~d}$ of age and remaining at that level throughout the remainder of the lactation period (Robles-Valdes et al. 1976). Carnitine was added at a concentration of $40 \mathrm{mg} / 1$ to ensure that an adequate concentration was present in the rat milk-substitutes. Picolinic acid has been implicated as the $\mathrm{Zn}$-binding ligand which facilitates the absorption of $\mathrm{Zn}$ through the intestinal lumen and has been found in the intestine of the rat (Evans, 1980). We added picolinic acid at a concentration similar to that reported for human milk (Evans, 1980). 
More recent evidence, however, suggests that picolinic acid may not be the essential $\mathrm{Zn}$ binding ligand (Eckhert, 1985).

\section{Milk and gastrointestinal status}

The growth rate of the rat pups on the artificial rearing system was standardized to growth rates observed for mother-reared pups by adjusting daily the infusion rate for the rat milksubstitutes. Rat pups were fed on RMS-2A in intermittent feeding periods of $10 \mathrm{~min} / \mathrm{h}$. Rat pups receiving RMS-2B were pulsed with milk for $10 \mathrm{~min} / \mathrm{h}$ to $13 \mathrm{~d}$ of age followed by 20 $\mathrm{min} / \mathrm{h}$ to $17 \mathrm{~d}$ of age. This longer feeding period allowed the rate of infusion to be slower and eliminated technical difficulties resulting in missed feeds. Others have employed feeding schedules of $15 \mathrm{~min} / \mathrm{h}$ (Tonkiss et al. 1985, 1987) as well as continuous-feeding schedules (Messer et al. 1969; West et al. 1982). The volume of milk normally ingested by sucking rats of different ages has been estimated by several invetigators (Henning, 1981; Coward et al. 1982; Knight et al. 1984). The quantities of RMS-2A and RMS-2B given $3.0 \mathrm{ml}$ at $4-5 \mathrm{~d}$ of age and $6.8 \mathrm{ml}$ at $9 \mathrm{~d}$ of age, are in good agreement with the calculated volumes of milk taken in by sucking rat pups, $3.8 \mathrm{ml}$ at $3-5 \mathrm{~d}$ of age and $6.8 \mathrm{ml}$ at $9-11 \mathrm{~d}$ of age (Coward et al. 1982).

The incidence of bloat in rat pups reared on our system was considerably less than that reported previously (Smart et al. 1984). We infer that this is because we keep the milk-filled syringes refrigerated at $7^{\circ}$ throughout the artificial-rearing period (Sonnenberg et al. 1982) instead of at room temperature as has been reported by others (Messer et al. 1969; West et al. 1982; Diaz et al. 1982; Tonkiss et al. 1985). We consider this a necessary precaution to reduce the potential for bacterial growth in the milk. Additional precautions to ensure healthy animals included obtaining pregnant rats reared in a specified-pathogen-free environment by the supplier, isolating rats for these experiments from other rat colonies at our facility, and housing them with dust-free maize-cob bedding to reduce the potential for respiratory stress. In the selection of animals for these experiments we considered it imperative to use only rat pups that were robust and maintained under stringent conditions.

A relatively high proportion of casein relative to whey protein in RMS-2A could be a contributing factor to hypertrophy of the gastrointestinal tract (Smart et al. 1984). We reasoned that if the fluidity of the rat milk-substitute could be enhanced (by increasing the relative proportion of whey) then hypertrophy of the stomach and small intestine would not occur. Our whey-enriched rat milk-substitute, RMS-2B, had a casein:whey ratio of $67: 33$; rat's milk has a casein:whey ratio of $76: 24$ (Woodward \& Messer, 1976). The stomach curds of rats reared on RMS-2B were more pliant than those of the MR-B rats and the weights of the stomachs were not different from those of the MR-B controls. However, the intestines continued to be elongated. The whey component of the milk may thus play a role in maintaining the fluidity of the milk as digestion begins in the acid-rich environment of the stomach, but does not appear to influence the extent of intestinal hypertrophy observed in artificially reared rats.

\section{Metabolism}

The concentration and turnover of key metabolites were measured as indicators of the metabolic status in the artificially reared rats. We were particularly interested in evaluating the status in blood of those metabolites that appeared to have been affected by the composition of the milk-substitute detailed by Messer et al. (1969). In our studies with this milk-substitute, RMS-1, we observed an apparent increase in glucose turnover and oxidation, a decrease in 3-hydroxybutyrate turnover and oxidation, and lower circulating concentrations of most of the essential amino acids compared with mother-reared rats 
(Sonnenberg et al. 1982). In the present studies with RMS-2-reared rats, carbohydrate and fat metabolism appeared to be normal, based on the concentration and turnover of glucose and 3-hydroxybutyrate in plasma and on their relative utilization for oxidative metabolism.

The circulating concentrations of the amino acids in the plasma of rat pups reared on the low protein RMS-1 were proportionately low in relation to the concentration of protein in that rat milk-substitute (Sonnenberg et al. 1982). In the present study, the concentration of protein in both RMS-2A and RMS-2B was within the range reported for rat's milk, and with the exception of serine and alanine, the concentrations of all the amino acids in plasma were not different from or were greater than those in their mother-reared controls (Tables 7 and 8). Only lysine and proline appear to be at higher concentrations in the casein of cow's milk compared with the casein of rat's milk (Woodward \& Messer, 1976). Although our analysis of the amino acid content of the protein in RMS-2B indicated that the concentration of lysine, but not proline, was higher than that in rat's milk (Table 3), the plasma concentrations of both lysine and proline, in addition to most of the other essential amino acids, were substantially higher in the artificially reared rats than in the motherreared control groups (Tables 7 and 8 ).

The circulating concentrations of the amino acids in the mother-reared rats appeared to be more tightly regulated than those in the RMS-2B-reared rats. Most of the essential and some of the non-essential amino acids in plasma of RMS-2B-reared rats were at concentrations which were substantially greater than for their mother-reared controls at both $20 \mathrm{~min}$ and $3 \mathrm{~h}$ after a feeding period (Table 8 ). The mean concentrations of the essential amino acids in the plasma of the MR-B group in the early post-prandial period were not statistically different from those measured at $3 \mathrm{~h}$ after a feeding episode (Table 8 ). By contrast there was a significant decrease in the concentration of most of the essential amino acids in the plasma of the RMS-2B group between $20 \mathrm{~min}$ and $3 \mathrm{~h}$ after a feeding period (Table 8). In addition, the gluconeogenic amino acids, serine and alanine, circulated at substantially lower concentrations in the RMS-2B-reared rats (Table 8): apparently a reflection of the lower concentrations of these amino acids supplied in the protein fraction of RMS-2B than in rat's milk protein. It is pertinent to indicate that the sulphur-containing amino acids are not well provided for in the protein of RMS-2B. Although the methionine content of the protein of the milk-substitute is about one half the content of methionine reported to be in the protein in rat's milk, the concentration of methionine in plasma of reared pups was higher than in the plasma of their MR-B controls in the early post-prandial period. The concentration of cysteine in plasma was not determined. These observations are worthy of further investigation because various infant formulas differ in their quantity of total protein (Robles, 1984; Janas, 1985).

Our approach to evaluating the efficacy of our rat milk-substitutes for protein metabolism in the artificially reared rats has been simple in nature. The observed differences in the concentrations of plasma amino acids in rats reared under different experimental conditions could be due not only to differences in rates of digestion of protein or absorption of individual amino acids, but also to differences in clearance from blood, turnover rates or other physiological mechanisms in effect as a result of the artificial rearing conditions or the composition of the rat milk-substitutes. Clearly, more definitive experiments will be required to evaluate how well the protein quality of RMS-2 satisfies protein requirements of neonatal rats during this period of development.

\section{Brain}

Appropriate contributions from protein, carbohydrate, fat and products of fat metabolism, the ketone bodies, are known to be important in early brain development (Dobbing, 1968; Hawkins et al. 1971; Webber \& Edmond, 1979; Yeh, 1980; Williamson, 1982; Lopes- 
Cardozo \& Klein, 1984; Lopes-Cardozo et al. 1984; Edmond et al. 1985). Ketone bodies serve as major oxidative substrates in brain during the neonatal period in both the rat (Hawkins et al. 1971 ; Page et al. 1971) and human being (Kraus et al. 1974) and as lipogenic precursors (Edmond, 1974; Webber \& Edmond, 1979; Yeh, 1980; Lopes-Cardozo \& Klein, 1984; Lopes-Cardozo et al. 1984), particularly during the peak period of myelination. We measured the concentrations of protein and two lipids, cholesterol and cerebroside sulphate, closely associated with myelin in the brains of 17-d-old RMS-2B-reared rats and found them at normal concentrations (Table 9).

Many enzymes in the brain show distinct developmental profiles. Land et al. (1977) reported that total pyruvate dehydrogenase was barely detectable until $5 \mathrm{~d}$ of age, attained $40 \%$ of the adult activity by $17-18 \mathrm{~d}$ of age and finally attained the adult activity by 30 $\mathrm{d}$ of age. By contrast, 3-oxo-acid-CoA transferase, responsible for activating acetoacetate in the mitochondria to acetoacetyl- $\mathrm{CoA}$ for subsequent oxidation, exhibits a transient increase during the pre-weaning period which is sustained over the myelination period followed by a decrease to adult activities (Page et al. 1971). Acetoacetyl-CoA ligase, the cytosolic enzyme committing acetoacetate to lipid synthesis, has an activity which is high during the entire pre-weaning period and decreases to adult activity after weaning (Buckley $\&$ Williamson, 1973). The activity of each of these three enzymes was normal at $17 \mathrm{~d}$ of age in the RMS-2B-reared rats.

Although these develomental markers in the brain were normal, brain weights in rats reared on RMS-2B were $93 \%$ of those in MR-B controls. This has also been observed by others (Diaz et al. 1982; Smart et al. 1984). It has been suggested by Smart et al. (1984) that this deficit in brain weight is a consequence of a metabolic adaptation induced by the procedure to cannulate and artificially rear rat pups. The physiological and developmental implications of the reduction in brain weight are not known. Novel approaches to improvements in the artificial rearing technique or the composition of the rat milksubstitute, or both, may be necessary to understand the determinant(s) for the reduced mass of brain tissue during this developmental period.

\section{Conclusions}

We conclude from our results that RMS-2A and RMS-2B are nutritionally satisfactory alternatives to rat's milk and can serve as a control diet in studies to examine the significance of nutrients in development. Our findings show that many developmental events appear to be normal in rat pups artificially reared on these milk-substitutes, while some developmental indices show unusual characteristics. Caution must be taken not to accept these milk-substitutes unequivocally as nutritionally appropriate in all areas of neonatal development. It is apparent that there is scope for improvement of the milk formulations. As requirements for particular nutrients are understood, further refinements in their composition can be addressed.

This work was supported by the United States Public Health Service grants HD11496 and HD12473. The authors thank Dr Young Ha (Coppell, TX) for advice; Dr Jim Smart (University of Manchester, England) for his interest and encouragement, Dr Michael Jones (School of Public Health, UCLA) for his advice and assistance with the analysis of amino acids; Ms Gwen Gordon (Statistician, Mental Retardation Center, UCLA) for her help with the statistical analysis; Ross Laboratories and Dr John Benson (Columbus, $\mathrm{OH}$ ) for their interest and support. 


\section{REFERENCES}

Altman, P. L. (1961). Physical properties and chemical composition of milk. In Blood and Other Body Fluids, pp. 453-466 [D. S. Dittmer, editor]. Washington, DC: Federation of American Societies for Experimental Biology.

Bailey, G. L., Clough, R. A. \& Dodd, F. H. (1955). The rate of secretion of milk and fat. Journal of Dairy Research 22, 22-36.

Bates, S. R. \& Rothblat, G. H. (1974). Regulation of cellular sterol flux and synthesis by human serum lipoprotein. Biochimica et Biophysica Acta 360, 38-55.

Bergstrom, J. D. \& Edmond, J. (1985). A radiochemical assay for acetoacety]-CoA synthetase. Analytical Biochemistry 149, 358-364.

Bradford, M. M. (1976). A rapid and sensitive method for the quantitation of microgram quantities of protein utilizing the principle of protein-dye binding. Analytical Biochemistry 72, 248-254.

Brandorff, N. P. (1980). The effect of dietary fat on the fatty acid composition of lipids secreted in rat's milk. Lipids 15, 276-277.

Buckley, B. M. \& Williamson, D. H. (1973). Acetoacetate and brain lipogenesis: developmental pattern of acetoacetyl-coenzyme A synthetase in the soluble fraction of rat brain. Biochemical Journal 132, 653-656.

Chalk, P. A. \& Bailey, E. (1979). Changes in the yield, and carbohydrate, lipid and protein content of milk during lactation in the rat. Journal of Developmental Physiology 1, 61-79.

Coward, W. A., Cole, T. J., Gerber, H., Roberts, S. B. \& Fleet, I. (1982). Water turnover and the measurement of milk intake. European Journal of Physiology 393, 344-347.

Cox, Jr., W. M. \& Mueller, A. J. (1937). The composition of milk from stock rats and an apparatus for milking small laboratory animals. Journal of Nutrition 13, $249 \cdots 261$.

Diaz, J., Moore, E., Petracca, F., Schacher, J. \& Stamper, C. (1982). Artificial rearing of rat pups with a proteinenriched formula. Journal of Nutrition 112, 841-847.

Diaz, J. \& Schain, R. J. (1977). Chronic phenobarbital administration: effects upon brain growth and behaviour of artificially-reared rats. Proceedings of the Western Pharmacology Society 20, 153-157.

Diaz, J. \& Schain, R. J. (1978). Phenobarbital: effects of long-term administration on behavior and brain of artificially-reared rats. Science 199, 90-91.

Dobbing, J. (1968). Vulnerable periods in developing brain. In Applied Neurochemistry, pp. 287-316 [A. N. Davison and J. Dobbing, editors]. Oxford: Blackwell.

Dymsza, H. A., Czajka, D. M. \& Miller, S. A. (1964). Influence of artificial diet on weight gain and body composition of the neonatal rat. Journal of Nutrition 84, 100-106.

Eckhert, C. D. (1985). Isolation of a protein from human milk that enhances zinc absorption in humans. Biochemical and Biophysical Research Communications 130, 264-269.

Edmond, J. (1974). Ketone bodies as precursors of sterols and fatty acids in the developing rat. Journal of Biological Chemistry 249, 72-80.

Edmond, J., Auestad, N., Robbins, R. A. \& Bergstrom, J. D. (1985). Ketone body metabolism in the neonate: development and the effect of diet. Federation Proceedings 44, 2359-2364.

Evans, G. W. (1980). Normal and abnormal zinc absorption in man and animals: the tryptophan connection. Nutrition Reviews 38, 137-141.

Ezekiel, E. (1967). Intestinal iron absorption by neonates and some factors affecting it. Journal of Laboratory and Clinical Medicine 70, 138-149.

Forsum, E. \& Lonnerdal, B. (1979). Variation in the contents of nutrients of breast milk during one feeding. Nutrition Reports International 19, 815-820.

Glass, R. L., Troolin, H. A. \& Jenness, R. (1967). Comparative biochemical studies of milks. IV. Constituent fatty acids of milk fats. Comparative Biochemistry and Physiology 22, 415-425.

Goda, T., Bustamante, S., Edmond, J., Grimes, J. \& Koldovsky, O. (1985a). Precocious increase of sucrase activity by carbohydrates in the small intestine of suckling rats. II. Role of digestibility of sugars, osmolality, and stomach evacuation in producing diarrhea. Journal of Pediatric Gastroenterology and Nutrition 4, 634-638.

Goda, T., Yamada, K., Bustamante, S., Edmond, J., Grimes, J. \& Koldovsky, O. (1985 b). Precocious inerease of sucrase activity by carbohydrates in the small intestine of suckling rats. I. Significance of the stress effect of sugar-induced diarrhea. Journal of Pediatric Gastroenterology and Nutrition 4, 468-475.

Godbole, V. Y., Grundleger, M. L., Pasquine, T. A. \& Thenen, S. W. (1981). Composition of rat milk from day 5 to 20 of lactation and milk intake of lean and preobese Zucker pups. Journal of Nutrition 111, $480-487$.

Grigor, M. R. \& Warren, S. M. (1980). Dietary regulation of mammary lipogenesis in lactating rats, Biochemicat Journal 188, 61-65.

Hall, W. G. (1975). Weaning and growth of artificially-reared rats. Science 190, 1313-1315.

Hawkins, R. A., Williamson, D. H. \& Krebs, H. A. (1971). Ketone-body utilization by adult and suckling rat brain in vivo. Biochemical Journal 122, 13-18.

Hegsted, D. M. (1973). Calcium and phosphorus. In Modern Nutrition in Health and Disease, Sth ed., pp. 268-286 [R. S. Goodhart and M. E. Shils, editors]. Philadelphia: Lea and Febiger.

Henning, S. J. (1981). Postnatal development: coordination of feeding, digestion and metabolism. American Journal of Physiology 241, G199-G214.

Hytten, F. E. (1954). Clinical and chemical studies in human lactation. British Medical Journal i, $174-182$. 
Janas, L. M. (1985). Indices of protein metabolism in term infants fed human milk whey predominant formula, or cow's milk formula. Pediatrics 75, 775-784.

Jenness, R. \& Sloan, R. E. (1970). The composition of milks of various species: a review. Dairy Science Abstracts 32, 599-612.

Jones, M. R. (1988). Free amino acid pools in the spontaneously hypertensive rat. A longitudinal study. Journal of Nutrition 118, 579-587.

Kean, E.L. (1968). Rapid, sensitive spectrophotometric method for quantitative determination of sulfatides. Journal of Lipid Research 9, 319-327.

Keen, C. L., Lonnerdal, B., Clegg, M. \& Hurley, L. S. (1981). Developmental changes in composition of rat milk: trace elements, minerals, protein, carbohydrate and fat. Journal of Nutrition 111, 226-230.

Knight, C. H., Docherty, A. H. \& Peaker, M. (1984). Milk yield in rats in relation to activity and size of the mammary secretory cell population. Journal of Dairy Research 51, 29-35.

Kraus, H., Schlenker, S. \& Schwedsky, D. (1974). Developmental changes of cerebral ketone body utilization in human infants. Hoppe-Seyler's Zeitschrift für Physiologische Chemie 355, 164-170.

Kris-Etherton, P. M., Layman, D. K., York, P. V. \& Frantz, I. D. (1979). The influence of early nutrition on the serum cholesterol of the adult rat. Journal of Nutrition 109, 1244-1257.

Ksiezak-Reding, H., Blass, J. P. \& Gibson, G. E. (1982). Studies on the pyruvate dehydrogenase complex in brain with the arylamine acetyl-transferase-coupled assay. Journal of Neurochemistry 38, 1627-1636.

Kuhn, N. J. (1972). The lactose and neuramin lactose content of rat milk and mammary tissue. Biochemicat Journal 130, $177-180$.

Land, J. M., Booth, R. F. G., Berger, R. \& Clark, J. B. (1977). Development of mitochondrial energy metabolism in rat brain. Biochemical Journal 164, 339-348.

Lonnerdal, B., Keen, C. L. \& Hurley, L. S. (1978). Iron, copper, zinc and manganese in milk. Annual Review of Nutrition 1, 149-174.

Lopes-Cardozo, M. \& Klein, W. (1984). Ketone-body utilization and lipid synthesis by developing rat brain - a comparison between in vivo and in vitro experiments. Neurochemistry International 6, 459-466.

Lopes-Cardozo, M., Koper, J. W., Klein, W. \& Van Golde, L M. G. (1984). Acetoacetate is a cholesterogenic precursor for myelinating rat brain and spinal cord. Incorporation of label from $\left[3-{ }^{14} \mathrm{C}\right]$ acetoacetate, $\left[{ }^{14} \mathrm{C}\right]$ glucose and ${ }^{3} \mathrm{H}_{2} \mathrm{O}$. Biochimica et Biophysica Acta 794, 350-352.

Luckey, T. D., Mende, T. J. \& Pleasants, J. (1954). The physical and chemical characterization of rat's milk. Journal of Nutrition 54, 345-359.

Messer, M., Thoman, E. B., Terrasa, A. G. \& Dallman, P. R. (1969). Artificial feeding of infant rats by continuous gastric infusion. Journal of Nutrition $98,404-410$.

Miller, S. A. \& Czajka, D. M. (1967). The influence of dietary osmolarity on survival in the neonatal rat. Biology of the Neonate 11, 197-203.

National Research Council (1978). Nutrient Requirements of Domestic Animals no. 10: Nutrient Requirements of Laboratory Animals, 3rd ed. Washington DC: National Academy of Sciences.

Page, M. A., Krebs, H. A. \& Williamson, D. H. (1971). Activities of enzymes of ketone body utilization in brain and other tissues of suckling rats. Biochemical Journal 121, 49-53.

Patton, M. B. \& Sutton, T. S. (1952). The utilization of calcium from lactate, gluconate, sulfate, and carbonate salts by young college women. Journal of Nutrition 48, 443-452.

Rassin, D. K., Sturman, J. A. \& Gaull, G. E. (1978). Taurine and other free amino acids in milk of man and other mammals. Early Human Development 2, 1-13.

Robles, R. (1984). Serum and urine amino acid patterns during the first month of life for small-to-date infants. Biology of the Neonate 45, 209-217.

Robles-Valdes, C., McGarry, J. D. \& Foster, D. W. (1976). Maternal-fetal carnitine relationships and neonatal ketosis in the rat. Journal of Biological Chemistry 251, 6007 -6012.

Smart, J. L., Massey, R. F., Nash, S. C. \& Tonkiss, J. (1987). Effects of early-life undernutrition in artificiallyreared rats: subsequent body and organ growth. British Journal of Nutrition 58, 245-255.

Smart, J. L., Stephens, D. N., Tonkiss, J., Auestad, N. S. \& Edmond, J. (1984). Growth and development of rats artificially-reared on different milk substitutes. British Journal of Nutrition 52, 227-237.

Smith, S., Watts, R. \& Dils, R. (1968). Quantitative gas-liquid chromatographic analysis of rodent milk triglycerides. Journal of Lipid Research $\mathbf{9}, 5257$.

Sonnenberg, N., Bergstrom, J. D., Ha, Y. H. \& Edmond, J. (1982). Metabolism in the artificially-reared rat pup; effect of an atypical rat milk substitute. Journal of Nutrition 112, 1506-1514.

Spray, C. M. (1950). A study of some aspects of reproduction by means of chemical analysis. British Journal of Nutrition 4, 354-360.

Thoman, E. B. \& Arnold, W. J. (1967). Effects of incubator rearing with social deprivation on maternal behaviour in rats. Journal of Comparative and Physiological Psychology 65, 44l-446.

Tonkiss, J., Smart, J. L., Auestad, N. S. \& Edmond, J. (1985). Type of milk substitute influences growth of the gastrointestinal tract in artificially-reared rat pups. Journal of Pediatric Gastroenterology and Nutrition $\mathbf{4}$, $818-825$

Tonkiss, J., Smart, J. L. \& Massey, R. F. (1987). Growth and development of rats artificially-reared on rats' milk/milk substitute combinations. British Journal of Nutrition 57, 3-11. 
Vernon, R. G. \& Walker, D. G. (1972). Glucose metabolism in the developing rat: studies in vivo. Biochemicat Journal 127, 521-529.

Webber, R. J. \& Edmond, J. (1977). Utilization of L(+)-3-hydroxybutyrate, D-(-)-3-hydroxybutyrate, acetoacetate and glucose for respiration and lipid synthesis in the 18-day-old rat. Journal of Biological Chemistry 252, 5222-5226.

Webber, R. J. \& Edmond, J. (1979). The in vivo utilization of acetoacetate, D( -)-3-hydroxybutyrate, and glucose for lipid synthesis in brain in the 18-day-old rat. Journal of Biological Chemistry 254, 3912-3920.

West, D. B., Diaz, J. \& Woods, S. C. (1982). Infant gastrostomy and chronic formula infusion as a technique to overfeed and accelerate weight gain of neonatal rats. Journal of Nutrition 112, 1339-1343.

Williamson, D. H. (1982). The production and utilization of ketone bodies in the neonate. In The Biochemical Development of the Fetus and the Neonate, pp. 621-650 [C. T. Jones, editor]. New York: Elsevier Biochemical.

Williamson, D. H., Bates, M. W., Page, M. A. \& Krebs, H. A. (1971). Activities of enzymes involved in acetoacetate utilization in adult and mammalian tissues. Biochemical Journal 121, 41-47.

Woodward, D. R. \& Messer, M. (1976). Chemical composition of rat casein. Comparative Biochemistry and Physiology 55, 141-143.

Yeh, K. Y. (1983). Small intestine of artificially-reared rat pups: weight gain and changes in alkaline phosphatase, lactase and sucrase activities during development. Journal of Nutrition 113, 1489-1495.

Yeh, Y. Y. (1980). Partition of ketone bodies into cholesterol and fatty acids in vivo in different brain regions of developing rats. Lipids $15,904-907$. 